\title{
Mortality from respiratory cancer and other causes in United Kingdom chromate production workers
}

\author{
J M Davies, D F Easton, P L Bidstrup
}

\section{Abstract}

This report updates a 1981 study of mortality at three United Kingdom chromate producing factories, and pays special attention to workers engaged after major plant and process changes were completed during 1958-60. The study covers 2298 payroll workers in post on 1 January 1950 or entering employment up to 30 June 1976 and remaining at least one year, with mortality observed up to 31 December 1988. Expected numbers of deaths were calculated from national death rates adjusted for social class and area differences. At the two largest factories 1422 men starting work before the process changes showed a highly significant excess of deaths from lung cancer (observed deaths/adjusted expected deaths (obs/expA) 175/88.97, adjusted standardised mortality ratio (SMRA) 197). They also had a significant excess of deaths from nasal cancer (obs/expA 4/0.26, SMRA 1538); the four affected men all had over 20 years of employment. Six hundred and seventy seven men starting work after the completion of process changes showed no excess of lung cancer deaths (obs/ expA 14/13.7, SMRA 102, 95\% confidence interval (95\% CI) 56-171), but the possibility of the risk persisting at a reduced level cannot be excluded. The risk among earlier entrants affected men with two or more years of employment and was highest among those working for 10 years or longer (SMRA 225). The relative risk was already raised 5-14 years after first employment; it was highest in the 25-40 year period, but was still raised 50 years after first exposure. The risk showed most clearly at young ages, with a SMRA of 355 for ages under 50 (obs/expA 21/5.91). The excess was greater among men in jobs with high exposure to chromates (obs/expA 151/61.73, SMRA 245) than among men in less' exposed

Section of Epidemiology, Institute of Cancer Research, Sutton, Surrey SM2 5NG

J M Davies, D F Easton

London SW1X 9DG

P L Bidstrup jobs (obs/expA 21/19.57, SMRA 107). Less evidence of a lung cancer excess was found among 199 men employed at a third small factory (obs/expA 12/9.91, SMRA 121). No risk was apparent in further groups of 214 salaried works staff (obs/expA 1/2.53), or 95 workers at an adjacent fertiliser plant (obs/expA'3/3.95). No significant excesses of deaths from cancers of other sites were found.

A probable cancer hazard to men employed in the production of chromates was indicated in 1950, when Baetjer $^{1}$ reviewed published work on respiratory cancer in chromate workers and found that 52 cases had been reported in German factories. Since then other studies in the United Kingdom, ${ }^{2-4}$ the United States, ${ }^{5-13}$ Japan, ${ }^{14}{ }^{15}$ Germany, ${ }^{16}$ and Italy ${ }^{17}$ have all shown a past or present lung cancer risk among workers in the industry. Substantial evidence also exists showing that a variety of hexavalent chromium compounds are carcinogenic in laboratory animals. ${ }^{18}$ Particularly, calcium chromate produces bronchial carcinomas after implantation in rats, and this compound is formed in the standard lime based kiln process.

It is not clear, however, to what extent if any the hazard persists for present day chromate workers, and no clear patterns of risk in relation to duration or level of exposure or to latent intervals have so far emerged, partly because numbers have been small in individual studies. The present study updates and extends earlier investigations into lung cancer in the United Kingdom chromate producing industry, ${ }^{2-4}$ investigates the patterns of risk, and pays special attention to the mortality of workers engaged after the completion of major process changes.

The first study in the United Kingdom was made by Bidstrup $^{2}$ who, in 1949 , interviewed and examined some 700 men employed at three chromate factories at Eaglescliffe (Teeside), Bolton (Greater Manchester), and Rutherglen (Glasgow); chest $x$ ray films of these men were also taken. One new case of lung cancer was found compared with an estimated expected number of 0.5. In 1955 Bidstrup and Case ${ }^{3}$ followed up the same group of men to their dates of leaving (ex-workers) or to 1955 for men staying at the works or retiring on pensions. Twelve deaths from lung cancer were found $v 3.3$ expected. This was a highly significant excess. The authors found no 
excess of deaths from all other neoplasms combined or from all causes combined.

In 1981 a further study of the same three factories by Alderson et $\mathrm{al}^{4}$ covered deaths from 1949 to 1977. Coverage was expanded to include 2715 men employed for at least one year, in post in 1949 , or engaged up to closure at Bolton and Rutherglen, and up to 1976 at Eaglescliffe; ex-workers were now traced. No excess of lung cancer deaths was seen at Bolton (five observed $v 4.98$ expected at national death rates), but an overall twofold excess was found at Eaglescliffe (obs/exp 36/16.70), and a nearly threefold excess at Rutherglen (obs/exp 75/26-28). This study also found some suggestion of a risk of cancer of the nose and nasal sinuses (two deaths observed $v 0.28$ expected), but no excess of other neoplasms. At the Rutherglen factory there was significant excess mortality from bronchitis (obs/exp $31 / 17 \cdot 40$ ), and from all other causes combined (obs/ exp 222/156.49). This study examined the lung cancer mortality of Eaglescliffe workers engaged after a change in 1960 to a "no lime" process, but the result was ambiguous owing to small numbers and short follow up.

\section{Materials and methods \\ FACTORIES AND PROCESSES \\ Chromates were produced from the 1820 s until closure in 1967 at the Rutherglen works, from 1893 until closure in 1966 at Bolton, and from 1928 at Eaglescliffe where production still continues. At the Eaglescliffe site a fertiliser plant was in production, from before the chromate plant was built until 1967, manufacturing superphosphates from phosphate rock and sulphuric acid. These two plants were some distance apart and had separate workforces but some men were transferred from one workforce to the other.}

The manufacturing processes and the workers' exposures have been essentially the same at all three factories. The first stage in manufacture is the production of sodium chromate from chromite ore containing trivalent chrome oxide in solid solution with other oxides. The ground chromite is reacted with an alkaline sodium salt at high temperatures in the presence of a supply of oxygen, thereby extracting the chromium and separating it from most of the other oxides and converting it to water soluble hexavalent sodium chromate. Because both the alkali source and the sodium chromate melt below the maximum reaction temperature, a third component is necessary in the mix to control the behaviour of the reaction product and optimise chromium extraction.

The third component added was formerly a calcium containing material such as lime, hydrated lime, limestone (calcium carbonate), or dolomite (calcium magnesium carbonate). In the standard high-lime kiln processes with a $56 \%$ lime to ore basis significant amounts of slowly soluble calcium chromate were formed and were present in the dusts to which workers were exposed. Exposures would have been especially high at Bolton and Rutherglen until hand fired furnaces were replaced by rotary kilns in the early 1940s; Eaglescliffe always had rotary kilns. Around 1957 developments began at Eaglescliffe aimed at eliminating any lime additions to the mix, and this was achieved by 1961 with the full implementation of a no-lime kiln process. From December 1974 to March 1978, however, small quantities of lime were intermittently used, with under $2 \%$ added on 347 days. The Rutherglen factory switched to a "low lime" process $(15 \%$ lime to ore basis) over the period 1957-59, but the small Bolton works retained the "high lime" process until closure.

In the current no-lime process the ground chromite ore is reacted with an alkali and an internally derived diluent. Frit leaving the kilns is continuously quenched in water and the slurry is subjected to adjustment of $\mathrm{pH}$ before filtration to separate the aqueous sodium chromate from the insoluble residues. After further purification processes, the sodium chromate solution is acidified with sulphuric acid to form sodium dichromate and sodium sulphate, and the sodium sulphate is crystallised for separation by suitably raising the sodium dichromate concentration by evaporation. The concentrated sodium dichromate solution is used as the raw material for the full range of hexavalent and trivalent chromium chemicals.

Apart from these major process changes, a steady series of plant and hygiene improvements reduced exposures at the plants from the mid-1950s onwards. Changes in the preparation and handling of raw materials, residues, and finished products were made, with improved kiln flue and ventilation systems and enclosed handling systems. Since mid-1955 all employees at the three works have had regular chest $x$ ray films taken, annually until 1961 and subsequently at eight month intervals. Since 1955 all potential new employees have had pre-employment medical examinations including $x$ ray films and a small proportion of applicants have been rejected on medical grounds.

Most work at the factories (and the fertiliser plant) has always been of an unskilled or semiskilled nature, and before the plant and process changes most jobs had some heavy and dusty manual work; labour turnover was high. Chrome ulcers of the skin and nose used to be common in the chromate plants, especially among new workers, and still occur at Eaglescliffe. Chrome ulcer cases notified at Eaglescliffe in the years 1957-61 totalled 43, 42, 31, 19, and 3 respectively (in a workforce of $400-500$ men); thereafter numbers remained low. Corresponding 
figures for the Rutherglen workforce of 500-600 men were $103,60,63,128$, and 36 ; incidence subsequently dropped, and the high number in 1960 may reflect the dusty conditions resulting from plant alterations and rebuilding. The Bolton and Rutherglen (Glasgow) factories were situated in areas with above average death rates, and most workers lived locally. Although the Eaglescliffe works is sited in the former Stockton Rural District, it is close to the Teesside nurbation, and only about a third of the study population lived in the immediate rural area.

\section{EMPLOYEE RECORDS}

The study population is substantially the same as that used in the 1981 survey except that unexposed office staff are omitted. It is based mainly on the medical records maintained and retained by one of us (PLB); few personnel or other records for ex-employees have been retained until recently. The earliest medical records date from the 1949 survey of most process workers and some other employees at the three works. A gap then exists until comprehensive medical examinations covered virtually all employees from 1955 onwards. Thus no medical records were extant for some men during 1949 or for those starting after 1949 and leaving before 1955 . No other records were available at Bolton or Rutherglen, but at Eaglescliffe some old non-medical records partly filled the gaps. Records of salaried works staff were less complete until 1955 and were complicated by transfers between different factories operated by the employers.

For most workers the records supplied names, dates of birth, addresses, dates of starting and leaving, and main jobs. For many men some crude information on smoking habits existed, but this was missing for so many workers entering employment before the late 1950s that it has not been used in the present analyses. For 1949 interviewees and entrants since 1955 information on earlier spells at the works and past employment elsewhere is also available. All records for study subjects were rechecked and past periods that had been previously overlooked were found for some men, especially at Rutherglen. Broken service was common: $27 \%$ of pre-1959 entrants at Rutherglen had more than one spell of chromate work, as had $6 \%$ of men at Bolton and $20 \%$ of pre-1961 entrants at Eaglescliffe where the situation is complicated by transfers between work on the chromate and fertiliser plants.

\section{STUDY DEFINITIONS}

The requirement for inclusion in the main study population of payroll employees was work with exposure to chromates which lasted at least one full year (in one or more spells) at any of the three works, some or all of this work being between 1 January 1950 and 30 June 1976; more recent entrants have been excluded because of short follow up. A few men already over age 64 on 1 January 1950 or over 59 when first engaged were excluded. Men working on the site but employed by outside contractors were also excluded unless they later joined the workforce, in which case their contracting work was taken into account. About 100 men included in the 1981 study $^{4}$ have been excluded as not fulfilling the new requirements, but a similar number of previously excluded but eligible men have been added.

A further population comprises staff employees fulfilling the same conditions, defined as men who had salaried staff status from the outset, and spent at least some of their time in the works; most were chemists, laboratory assistants, works managers, and engineers. Staff are combined for all three factories as numbers are small and transfers between the factories were common. Men who started employment as hourly paid workers remain in the main population even if they later achieved staff status, for example as foremen. A further control group comprises Eaglescliffe men who never worked in or near the chromate plant, but worked in the fertiliser or sulphuric acid plants, or as mechanics in the garage. For convenience this is termed the "fertiliser" group. Table 1 shows the numbers of men. The main population of chromate exposed payroll workers totals 2298 men.

There are three main groups of payroll workers in relation to starting date (tables 1 and 3). Men who started work before 1 January 1945 are termed "early" workers and are, by definition, long service men who entered observation in 1950 long after their first chrome exposure; they do not form complete cohorts, as their contemporary workmates who left or died before 1950 are excluded. Men who joined from 1 January 1945 up to 31 December 1958 at Rutherglen, or up to 31 December 1960 at Eaglescliffe are termed "prechange" workers, as some or all of their work preceded the major process changes; for convenience Bolton men starting from 1945 are also termed "prechange." Cohorts of prechange men are also incomplete, because those leaving during 194649 cannot be included, and because of gaps in the later records. Prechange groups, however, are complete for all eligible men starting after 1953, and for all men staying for five years or longer.

Men starting after the process changes at Eaglescliffe and Rutherglen became fully effective are termed "postchange" workers, and form complete cohorts. There is a corresponding small group of postchange staff for both works, but all salaried staff starting earlier are combined in one small group of "prechange staff." Men in the fertiliser plant had starting dates ranging from 1925 to 1965.

\section{TRACING}

Follow up information (including death certificates) was available from the firms for current employees 
Table 1 Numbers of men and man-years, and trace state at 1 January 1989

\begin{tabular}{|c|c|c|c|c|c|c|c|c|}
\hline $\begin{array}{l}\text { Factory } \\
\text { group }\end{array}$ & $\begin{array}{l}\text { Starting } \\
\text { dates }\end{array}$ & Untraced & Emigrated & Dead & Alive & Total & Man-years & $\begin{array}{l}\text { (Worked } \\
>10 \text { years) }\end{array}$ \\
\hline $\begin{array}{l}\text { Bolton: } \\
\text { Early } \\
\text { Prechange }\end{array}$ & $\begin{array}{r}1909-44 \\
1945-65\end{array}$ & $\begin{array}{r}0 \\
16\end{array}$ & $\begin{array}{l}0 \\
3\end{array}$ & $\begin{array}{l}33 \\
66\end{array}$ & $\begin{array}{r}4 \\
77\end{array}$ & $\begin{array}{r}37 \\
162\end{array}$ & $\begin{array}{r}817 \\
3634\end{array}$ & $\begin{array}{l}(37) \\
(27)\end{array}$ \\
\hline $\begin{array}{l}\text { Rutherglen: } \\
\text { Early } \\
\text { Prechange } \\
\text { Postchange }\end{array}$ & $\begin{array}{l}1902-44 \\
1945-58 \\
1959-66\end{array}$ & $\begin{array}{r}13 \\
26 \\
1\end{array}$ & $\begin{array}{l}3 \\
9 \\
4\end{array}$ & $\begin{array}{r}264 \\
193 \\
47\end{array}$ & $\begin{array}{r}46 \\
212 \\
156\end{array}$ & $\begin{array}{l}326 \\
440 \\
208\end{array}$ & $\begin{array}{r}6416 \\
11006 \\
4866\end{array}$ & $\begin{array}{c}(300) \\
(178) \\
(-)\end{array}$ \\
\hline $\begin{array}{l}\text { Eaglescliffe: } \\
\text { Early } \\
\text { Prechange } \\
\text { Postchange } \\
\text { Fertilisers` }\end{array}$ & $\begin{array}{l}1928-44 \\
1945-60 \\
1961-76 \\
1906-67\end{array}$ & $\begin{array}{r}1 \\
13 \\
0 \\
2\end{array}$ & $\begin{array}{r}0 \\
16 \\
9 \\
1\end{array}$ & $\begin{array}{r}65 \\
217 \\
44 \\
38\end{array}$ & $\begin{array}{r}13 \\
331 \\
416 \\
54\end{array}$ & $\begin{array}{r}79 \\
577 \\
469 \\
95\end{array}$ & $\begin{array}{r}1784 \\
15717 \\
7826 \\
2422\end{array}$ & $\begin{array}{r}(75) \\
(228) \\
(196) \\
(38)\end{array}$ \\
\hline $\begin{array}{l}\text { All staff: } \\
\text { Prechange† } \\
\text { Postchange† }\end{array}$ & & $\begin{array}{l}5 \\
2\end{array}$ & $\begin{array}{l}3 \\
6\end{array}$ & $\begin{array}{r}26 \\
4\end{array}$ & $\begin{array}{r}68 \\
100\end{array}$ & $\begin{array}{l}102 \\
112\end{array}$ & $\begin{array}{l}2750 \\
2081\end{array}$ & $\begin{array}{l}(47) \\
(29)\end{array}$ \\
\hline Total & & $\begin{array}{l}79 \\
3.0 \%\end{array}$ & $\begin{array}{l}54 \\
2 \cdot 1 \%\end{array}$ & $\begin{array}{l}997 \\
38.2 \%\end{array}$ & $\begin{array}{l}1477 \\
56.7 \%\end{array}$ & $\begin{array}{l}2607 \\
100 \%\end{array}$ & 59319 & $\begin{array}{l}(1155) \\
(44 \cdot 3 \%)\end{array}$ \\
\hline
\end{tabular}

${ }^{\star}$ Includes 10 garage and 10 sulphuric acid plant workers. Man-years include some data for 32 further men starting in fertilisers but later moving to chromates.

† Staff starting before 1959 at Rutherglen; before 1961 at Eaglescliffe.

† Staff starting from 1959-66 at Rutherglen; from 1961-76 at Eaglescliffe.

and most retirement pensioners. Most ex-workers were traced and flagged by the National Health Service Central Register (NHSCR) or the Scottish General Register Office (GRO). For some early workers the information in the medical records was scant and insufficient for tracing, and these men were omitted from the 1981 study. All such men have now been included (at least until lost), and efforts have been made to ascertain further details and achieve tracing. National Insurance numbers were known for most workers, and the vital state of some men untraced by the NHSCR or the GRO was traced through referral to the Department of Health and Social Security. All previous follow up data were reviewed, and doubtful traces from any source were checked and sometimes amended. Eleven further lung cancer deaths were ascertained among men previously excluded, untraced, or mistraced. Causes of death were ascertained for all except three of the 997 deceased men.

As shown in table 1,79 workers were untraced and a further 54 emigrated, giving a total of 133 men lost to follow up $(5 \cdot 1 \%)$. The percentages lost were highest for Bolton prechange men (12\%), Rutherglen prechange workers $(8 \%)$, and salaried staff $(7 \cdot 5 \%)$. Only $2 \%$ of postchange workers were lost.

\section{METHODS OF ANALYSIS}

Workers enter observation on 1 January 1950 or on completion of one year's work if later, with the exception of some men observed only from mid-1955 because their earliest records were those of the second $x$ ray film survey. Man-years at risk were calculated up to the study closing date of 31 December 1988 or up to earlier death, emigration, or becoming untraced. Follow up stopped at age 85 . Eaglescliffe men who moved from the fertiliser plant to the chromate plant were considered to become chromate workers on the day of their transfer; 32 such men who moved after 1 January 1950 had their man-years before their transfer date added to the fertiliser group's experience. Fertiliser work was disregarded for men with previous chromate exposure. Mortality analyses were made for each of the 11 groups shown in table 1 .

Mortality from lung cancer was further analysed by broad job categories. Information about the workers' jobs was incomplete and of variable quality and many men changed jobs. It was not feasible to do more than classify each man by what was considered to be his most chrome exposed job. The five categories were:

(1) process workers, general workers, labourers, plant cleaners, jobs unknown;

(2) mates (assistants) to fitters, to electricians, and to other skilled tradesmen;

(3) warehouse workers, drivers and other transport workers;

(4) fitters, riggers, electricians, joiners, plumbers, and other skilled tradesmen;

(5) yard men, steam and power workers, timekeepers, first aid attendants, laundry workers, and other service workers.

The first category accounts for nearly two thirds of the main study population, and skilled craftsmen form about $18 \%$. Men in the final category generally had the least exposure to chromates. 
Deaths were coded to the International Classification of Diseases (ICD) revision in force at the date of death. Expected numbers of deaths were calculated by the standard method of multiplying the personyears by the appropriate mortality, using the "person-years" computer program. ${ }^{19}$ Person-years were computed for each five year age group up to age 84 , for the periods $1950-55,1956-60,1961-65$, 1966-70, 1971-75, 1976-80, 1981-85, and 1986-88. Mortalities for England and Wales were supplied by the Office of Population Censuses and Surveys; 1986-87 rates were used for the period 1986-88. Rates for Scotland were compiled from data supplied by the Scottish General Register Office, with 198186 rates used for the whole period 1981-88. For the purpose of these analyses lung cancer is taken to include carcinoma of the bronchus (ICD 162 in the 9 th revision) and lung neoplasms of unspecified nature (ICD 239.1); two deaths were assigned to the last classification.

The analyses only use the assigned certified cause of death, and exclude 13 other cases of lung cancer known to have occurred during the period 1950-88; 10 where death was assigned to other causes, one where a man was treated for lung cancer but was later lost to follow up, and two cases where men are alive three and 11 years after surgery.

Expected values for most causes of death were adjusted to allow for area and class differences between the study groups and the average national populations. The adjustment factors used (table 12) are described in the appendix. They are based on national social class data for England and Wales for $1970-72,{ }^{20}$ on $1968-78$ area data ${ }^{21-23}$ for Bolton and Eaglescliffe payroll workers, and 1969-73 area data $^{24-26}$ for Rutherglen men. Most of the hourly paid workers had unskilled or semiskilled jobs, and social class IV standardised mortality ratios (SMRs) were used to give class adjustment factors for each main cause of death. Local area SMRs were then examined, and combined class and area factors were calculated incorporating the residual local variation from national rates after allowing for the social class structure of the area. Most salaried staff were professionally qualified and many lived elsewhere in the United Kingdom before or after their employment at the factories. Adjustment factors for staff are therefore based only on national social class II SMRs without any further area adjustment.

As well as the main non-neoplastic causes shown in table 11, analyses were made for the following disease groups (with ICD 9th revision codes): infective and parasitic diseases (001-139), tuberculosis (010-018), diabetes (250), diseases of the blood etc (280-289), mental disorders (290-315), diseases of the nervous system etc (320-389), hypertensive disease (400405), other heart diseases (390-398, 415-429), influenza and pneumonia (480-487), diseases of the digestive system (520-579), gastric ulcers (531-534), chronic liver disease (571), diseases of the genitourinary system (580-611), nephritis (580-589), and suicide, etc (E950-959, 980-989). Significance tests for SMRs are based on the Poisson distribution and are two tailed.

\section{Results}

Table 2 gives overall results for lung and nasal cancers. At both Eaglescliffe and Rutherglen significant excesses of lung cancer deaths are found among early and prechange workers. At Bolton there is a non-significant excess among prechange men. No

Table 2 Mortality from lung and nasal cancer by works and group

\begin{tabular}{|c|c|c|c|c|c|c|c|c|}
\hline & \multicolumn{4}{|c|}{ Lung cancer } & \multicolumn{4}{|c|}{ Nasal cancer } \\
\hline & Obs & $\operatorname{Exp} A$ & $S M R A$ & $(S M R N)$ & Obs & $\operatorname{Exp} A$ & $S M R A$ & $(S M R N)$ \\
\hline $\begin{array}{l}\text { Bolton: } \\
\text { Early } \\
\text { Prechange }\end{array}$ & $\begin{array}{r}2 \\
10\end{array}$ & $\begin{array}{l}3 \cdot 14 \\
6 \cdot 77\end{array}$ & $\begin{array}{r}64 \\
148\end{array}$ & $\begin{array}{r}(82) \\
(189)\end{array}$ & $\begin{array}{l}0 \\
0\end{array}$ & $\begin{array}{l}0.01 \\
0.02\end{array}$ & $\overline{-}$ & $\begin{array}{l}(-) \\
(-)\end{array}$ \\
\hline $\begin{array}{l}\text { Rutherglen: } \\
\text { Early } \\
\text { Prechange } \\
\text { Postchange }\end{array}$ & $\begin{array}{r}68 \\
41 \\
8\end{array}$ & $\begin{array}{r}29 \cdot 56 \\
25 \cdot 59 \\
8 \cdot 21\end{array}$ & $\begin{array}{l}230^{\star \star \star} \\
160^{\star \star \star} \\
97\end{array}$ & $\begin{array}{l}(347)^{\star \star \star} \\
(242)^{\star \star \star} \\
(147)\end{array}$ & $\begin{array}{l}2 \\
0 \\
0\end{array}$ & $\begin{array}{l}0 \cdot 07 \\
0.05 \\
0 \cdot 02\end{array}$ & $\begin{array}{l}3042^{\star \star} \\
-\end{array}$ & $\begin{array}{l}(2852)^{\star \star} \\
(-) \\
(-)\end{array}$ \\
\hline $\begin{array}{l}\text { Eaglescliffe: } \\
\text { Early } \\
\text { Prechange } \\
\text { Postchange } \\
\text { Fertiliser }\end{array}$ & $\begin{array}{r}14 \\
52 \\
6 \\
3\end{array}$ & $\begin{array}{r}7 \cdot 14 \\
26 \cdot 68 \\
5 \cdot 51 \\
3 \cdot 95\end{array}$ & $\begin{array}{l}196^{\star} \\
195^{\star \star \star} \\
109 \\
76\end{array}$ & $\begin{array}{l}(269)^{\star} \\
(267)^{\star \star \star} \\
(149) \\
(104)\end{array}$ & $\begin{array}{l}0 \\
2 \\
0 \\
0\end{array}$ & $\begin{array}{l}0.03 \\
0.11 \\
0.03 \\
0.02\end{array}$ & $\begin{array}{l}\overline{1824^{\star \star}} \\
-\end{array}$ & $\begin{array}{l}(-) \\
(2024)^{\star \star} \\
(-)\end{array}$ \\
\hline $\begin{array}{l}\text { Staff: } \\
\quad \text { Prechange } \\
\text { Postchange }\end{array}$ & $\begin{array}{l}1 \\
0\end{array}$ & $\begin{array}{l}1.95 \\
0.58\end{array}$ & 51 & $\begin{array}{l}(34) \\
(-)\end{array}$ & $\begin{array}{l}0 \\
0\end{array}$ & $\begin{array}{l}0.01 \\
0.00\end{array}$ & 二 & $\begin{array}{l}(-) \\
(-)\end{array}$ \\
\hline
\end{tabular}

${ }^{\star} \mathrm{p}<0.05$ (two tailed); ${ }^{\star \star} \mathrm{p}<0.01$ (two tailed); ${ }^{\star \star \star} \mathrm{p}<0.001$ (two tailed).

ExpA and SMRA adjusted for class and area, SMRN based on national unadjusted rates. SMRs based on fewer than five observed deaths shown in italics (this applies to all tables). 
Table 3 Lung cancer mortality by years of starting work

\begin{tabular}{|c|c|c|c|c|c|c|c|}
\hline \multirow{3}{*}{$\begin{array}{l}\text { Year of } \\
\text { starting }\end{array}$} & \multicolumn{3}{|c|}{ Rutherglen } & \multicolumn{4}{|c|}{ Eaglescliffe } \\
\hline & \multirow{2}{*}{$\begin{array}{l}\text { No of } \\
\text { men }\end{array}$} & \multicolumn{2}{|l|}{ Lung cancer } & \multirow{2}{*}{$\begin{array}{l}\text { Year of } \\
\text { starting }\end{array}$} & \multirow{2}{*}{$\begin{array}{l}\text { No of } \\
\text { men }\end{array}$} & \multicolumn{2}{|l|}{ Lung cancer } \\
\hline & & $O b s / E x p A$ & $S M R A$ & & & $O b s / E x p A$ & $S M R A$ \\
\hline \multicolumn{8}{|c|}{ Early workers } \\
\hline $\begin{array}{l}1902-25 \\
1925-34 \\
1935-44\end{array}$ & $\begin{array}{r}96 \\
93 \\
137\end{array}$ & $\begin{array}{l}21 / 8.68 \\
16 / 9.67 \\
31 / 11 \cdot 21\end{array}$ & $\begin{array}{l}242 \\
165 \\
277\end{array}$ & $\begin{array}{l}1928-34 \\
1935-44\end{array}$ & $\begin{array}{l}28 \\
51\end{array}$ & $\begin{array}{r}4 / 3.35 \\
10 / 3.79\end{array}$ & $\begin{array}{l}119 \\
264\end{array}$ \\
\hline \multicolumn{8}{|c|}{ Prechange workers } \\
\hline $\begin{array}{l}1945-49 \\
1950-54 \\
1955-58\end{array}$ & $\begin{array}{r}143 \\
87 \\
210\end{array}$ & $\begin{array}{l}14 / 10 \cdot 64 \\
11 / 4.53 \\
16 / 10 \cdot 43\end{array}$ & $\begin{array}{l}132 \\
243 \\
153\end{array}$ & $\begin{array}{l}1945-49 \\
1950-54 \\
1955-60\end{array}$ & $\begin{array}{l}152 \\
192 \\
231\end{array}$ & $\begin{array}{l}19 / 8 \cdot 47 \\
23 / 8 \cdot 63 \\
10 / 9 \cdot 51\end{array}$ & $\begin{array}{l}224 \\
267 \\
105\end{array}$ \\
\hline \multicolumn{8}{|c|}{ Postchange workers } \\
\hline $\begin{array}{l}1959-60 \\
1961-66\end{array}$ & $\begin{array}{r}116 \\
92\end{array}$ & $\begin{array}{l}5 / 5 \cdot 27 \\
3 / 2.95\end{array}$ & $\begin{array}{r}95 \\
102\end{array}$ & $\begin{array}{l}1961-65 \\
1966-70 \\
1971-76\end{array}$ & $\begin{array}{r}59 \\
220 \\
190\end{array}$ & $\begin{array}{l}2 / 1 \cdot 24 \\
4 / 3 \cdot 52 \\
0 / 0 \cdot 75\end{array}$ & $\begin{array}{l}161 \\
114 \\
\end{array}$ \\
\hline
\end{tabular}

Table 4 Lung cancer by duration of service: Rutherglen and Eaglescliffe early and prechange men

\begin{tabular}{|c|c|c|c|c|c|c|c|c|c|}
\hline \multirow[b]{3}{*}{ Group } & \multicolumn{7}{|c|}{ Duration of service } & \multirow{2}{*}{\multicolumn{2}{|c|}{ Total }} \\
\hline & \multirow{2}{*}{$\begin{array}{l}1 \text { year } \\
\text { Obs/ExpA }\end{array}$} & \multirow{2}{*}{$\begin{array}{l}2-4 \text { years } \\
\text { Obs/ExpA }\end{array}$} & \multirow{2}{*}{$\begin{array}{l}\text { 5-9 years } \\
\text { Obs/ExpA }\end{array}$} & \multirow{2}{*}{$\begin{array}{l}10-19 \text { years } \\
O b s / \operatorname{Exp} A\end{array}$} & \multirow{2}{*}{$\begin{array}{l}20-29 \text { years } \\
O b s / E x p A\end{array}$} & \multirow{2}{*}{$\begin{array}{l}30-39 \text { years } \\
\text { Obs/ExpA }\end{array}$} & \multirow{2}{*}{$\begin{array}{l}\geqslant 40 \text { years } \\
\text { Obs/ExpA }\end{array}$} & & \\
\hline & & & & & & & & $O b s / \operatorname{Exp} A$ & $S M R A$ \\
\hline \multicolumn{10}{|l|}{ Early: } \\
\hline Rutherglen & $0 / 0.01$ & $2 / 0.30$ & $2 / 1.51$ & $9 / 5.30$ & $28 / 9.57$ & $19 / 9.66$ & $8 / 3 \cdot 21$ & $68 / 29 \cdot 56$ & 230 \\
\hline Eaglescliffe & $0 / 0.00$ & $0 / 0.01$ & $0 / 0.55$ & 1) 1.45 & $9 / 1.91$ & 4/ 2.50 & $0 / 0 \cdot 72$ & $14 / 7 \cdot 14$ & 196 \\
\hline Subtotal & $0 / 0.01$ & $2 / 0.31$ & $2 / 2.06$ & $10 / 6.75$ & $37 / 11 \cdot 48$ & $23 / 12 \cdot 16$ & $8 / 3.93$ & $82 / 36 \cdot 70$ & 223 \\
\hline SMRA & & 645 & 97 & 148 & 322 & 189 & 204 & & \\
\hline \multicolumn{10}{|l|}{ Prechange: } \\
\hline Rutherglen & $3 / 1.89$ & $9 / 6.13$ & $3 / 4.91$ & $26 / 10 \cdot 76$ & $0 / 1.71$ & $0 / 0.20$ & - & $41 / 25 \cdot 59$ & 160 \\
\hline $\begin{array}{l}\text { Eaglescliffe } \\
\text { Subtotal }\end{array}$ & $0 / 5 \cdot 77$ & $15 / 5 \cdot 21$ & $\begin{array}{r}9 / 3.96 \\
12 / 8.87\end{array}$ & $13 / 6 \cdot 33$ & $8 / 4.04$ & 7) 1.36 & $0 / 0.01$ & $52 / 26 \cdot 68$ & 195 \\
\hline $\begin{array}{l}\text { Subtotal } \\
\text { SMRA }\end{array}$ & $\begin{array}{l}317 \cdot 60 \\
39\end{array}$ & $\begin{array}{l}24 / 11 \cdot 34 \\
212\end{array}$ & $\begin{array}{l}12 / 8 \cdot 87 \\
135\end{array}$ & $\begin{array}{l}39 / 17 \cdot 09 \\
228\end{array}$ & $\begin{array}{l}8 / 5 \cdot 75 \\
139\end{array}$ & $\begin{array}{r}7 / 1.56 \\
449\end{array}$ & $-^{0 / 0.01}$ & $93 / 52 \cdot 27$ & 178 \\
\hline \multirow{3}{*}{$\begin{array}{l}\text { Total } \\
\text { SMRA }\end{array}$} & $3 / 7 \cdot 68$ & $26 / 11 \cdot 65$ & $14 / 10.93$ & $49 / 23 \cdot 84$ & $45 / 17 \cdot 23$ & $30 / 13 \cdot 72$ & $8 / 3.94$ & $175 / 88 \cdot 97$ & 197 \\
\hline & 39 & 223 & 128 & 206 & 261 & 219 & 203 & & \\
\hline & \multicolumn{7}{|c|}{ Postchange work years excluded } & & \\
\hline Total & $18 / 14 \cdot 98$ & $29 / 16 \cdot 18$ & $29 / 14 \cdot 27$ & $52 / 21 \cdot 62$ & $28 / 12 \cdot 31$ & $17 / 8.65$ & $2 / 0.96$ & $175 / 88 \cdot 97$ & 197 \\
\hline & 120 & 179 & 203 & 241 & 227 & 197 & 208 & & \\
\hline
\end{tabular}

Table 5 Lung cancer mortality by duration of service and interval after start of employment: Rutherglen and Eaglescliffe early and prechange men

\begin{tabular}{|c|c|c|c|c|c|c|c|c|}
\hline \multirow{3}{*}{$\begin{array}{l}\text { Years } \\
\text { from } \\
\text { start } \\
\text { of work }\end{array}$} & \multicolumn{8}{|c|}{ Duration of service } \\
\hline & \multicolumn{2}{|l|}{1 year } & \multicolumn{2}{|l|}{$2-4$ years } & \multicolumn{2}{|l|}{ 5-9 years } & \multicolumn{2}{|l|}{ 10-19 years } \\
\hline & $O b s / E x p A$ & $S M R A$ & $O b s / E x p A$ & $S M R A$ & $O b s / E x p A$ & $S M R A$ & $O b s / E x p A$ & $S M R A$ \\
\hline $\begin{array}{l}1-4 \\
5-14 \\
15-24 \\
25-34 \\
35-44 \\
\geqslant 45\end{array}$ & $\begin{array}{l}0 / 0.46 \\
0 / 1.35 \\
0 / 2 \cdot 70 \\
2 / 2 \cdot 71 \\
1 / 0.46 \\
-\end{array}$ & $\begin{array}{r}\overline{-} \\
\overline{74} \\
217\end{array}$ & 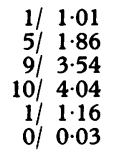 & $\begin{array}{r}99 \\
269 \\
254 \\
248 \\
86 \\
-\end{array}$ & $\begin{array}{ll}4 / 3.26 \\
6 / 2 & 2.48 \\
2 / 3.35 \\
2 / 1.64 \\
0 / & 0.24\end{array}$ & $\begin{array}{r}123 \\
242 \\
60 \\
122 \\
-\end{array}$ & $\begin{array}{r}5 / 3.48 \\
19 / 9.81 \\
16 / 7.21 \\
8 / 2.47 \\
1 / 0.87\end{array}$ & $\begin{array}{l}144 \\
194 \\
222 \\
324 \\
115\end{array}$ \\
\hline Total & $3 / 7 \cdot 68$ & 39 & $26 / 11 \cdot 65$ & 223 & $14 / 10.93$ & 128 & $49 / 23.84$ & 206 \\
\hline
\end{tabular}


apparent excesses occur in the postchange groups, in the less exposed staff groups, or in the non-exposed fertiliser group. Nasal cancers show a highly significant overall excess with two cases at Eaglescliffe and two at Rutherglen.

\section{LUNG CANCER}

Table 3 shows mortality from lung cancer among Eaglescliffe and Rutherglen payroll workers by date of starting work. At Eaglescliffe the estimated risk is lower for prechange men first employed between 1955-60 (SMRA (A = adjusted; see appendix) 105) than for those who started during 1945-54 (SMRA 267) although the difference is not significant. If the comparison is limited to men with at least two years' work, observed from 5-29 years after first employment, the SMRAs are 135 (observed deaths/ adjusted expected deaths (obs/expA) 8/5.91) for 1955-60 entrants compared with 285 (obs/expA 25/ 8.76) for 1945-54 starters. Rutherglen workers starting work during 1955-58 may also have a lower risk than their predecessors.

Table 4 shows mortality by duration of service for early and prechange workers. Many men had service spanning the process change dates, and the years they worked after the changes are included although it is uncertain whether these postchange years added to their pre-existing risk. A deficit of deaths from lung cancer exists among men with only one year's work (obs/expA 3/7.68), with no deaths at Eaglescliffe. Observed deaths are more than double those expected in the 2-4 year division (SMRA 223), with excesses for two, three, and four year subdivisions of obs/expA $11 / 5 \cdot 57,6 / 3 \cdot 32$, and $9 / 3 \cdot 78$. The overall relative risk drops for men staying 5-9 years, but thereafter is about doubled overall for each division. No gradient of risk by total duration of service is apparent, and some inconsistencies exist between the results for early and prechange men and those for the two factories.

The pattern of risk by duration of service is somewhat different if postchange years of work are excluded, as shown in the analysis at the foot of table 4. There is now a significant trend of increasing risk with increasing duration of employment $(p=0.04)$, rising up to $10-19$ years with a subsequent slight decline. The redefined 5-9 years division shows a considerably higher excess, with SMRAs of 135 at Rutherglen, and 305 at Eaglescliffe. A slight excess also occurs among men with less than two years' prechange work; most of the additional cases are among Rutherglen men who started shortly before the process change and stayed on afterwards. The anomalous deficit among Eaglescliffe one year workers in the first analysis is now much less striking and is non-significant (obs/expA 4/7.73).

Table 5 shows lung cancer mortality for the four groups combined, simultaneously by duration of service and by interval after first chrome exposure with years of postchange work included. There is no indication of excess mortality within 1-4 years from first exposure, but some excess is apparent in the 5-9 year interval (obs/expA 6/3.61). The relative risk rises to its highest level between 35 and 39 years after first exposure (SMRA 262), and subsequently declines. Early and prechange groups show similar patterns by interval from first exposure; early workers contribute most of the experience after 35 years.

Table 6 shows lung cancer by age at death; in the early groups experience at the youngest age groups is restricted by delayed entry into observation. Among early and prechange men the SMRAs are highest at young ages and decline with advancing age. The relative risk is high at ages $30-39$, with five deaths observed compared with only 0.61 expected. The five men concerned all worked at Eaglescliffe, and include four prechange workers employed before 1955; two died aged only 30. Although the overall SMRA for Bolton early and prechange workers is only 121 (obs/expA 12/9.91), the results by age are suggestive of the same pattern, with SMRAs of 317 (obs/expA 2/0.63) for ages under 50, 116 (obs/expA $3 / 2 \cdot 59$ ) for ages $50-59,117$ (obs/expA $5 / 4 \cdot 28$ ) for ages $60-69$, and 83 (obs/expA 2/2.42) for ages over 70 .

Table 7 shows mortality by broad job categories for Eaglescliffe and Rutherglen workers with at least two years' employment. These analyses are somewhat crude, as each worker was assigned to only one

\begin{tabular}{|c|c|c|c|c|c|c|c|}
\hline \multicolumn{2}{|l|}{ 20-29 years } & \multicolumn{2}{|l|}{ 30-39 years } & \multicolumn{2}{|l|}{$\geqslant 40$ years } & \multicolumn{2}{|l|}{ Total } \\
\hline $\begin{array}{r}8 / 3.49 \\
27 / 8.25 \\
10 / 4.11 \\
0 / 1.34\end{array}$ & $\begin{array}{l}229 \\
327 \\
243 \\
-\end{array}$ & $\begin{array}{r}9 / 2 \cdot 73 \\
13 / 6 \cdot 38 \\
8 / 4.61\end{array}$ & $\begin{array}{l}330 \\
204 \\
174\end{array}$ & $\begin{array}{l}4 / 0 \cdot 84 \\
4 / 3 \cdot 07\end{array}$ & $\begin{array}{l}476 \\
130\end{array}$ & $\begin{array}{r}1 / 1 \cdot 47 \\
14 / 9.94 \\
42 / 22 \cdot 01 \\
66 / 28 \cdot 29 \\
39 / 17.09 \\
13 / 10 \cdot 17\end{array}$ & \begin{tabular}{r|}
68 \\
141 \\
191 \\
233 \\
228 \\
128
\end{tabular} \\
\hline
\end{tabular}


Table 6 Lung cancer by age at death: Rutherglen and Eaglescliffe

\begin{tabular}{|c|c|c|c|c|c|c|}
\hline \multirow{2}{*}{$\begin{array}{l}\text { Age at } \\
\text { death (y) }\end{array}$} & \multicolumn{2}{|c|}{ Early: both works } & \multicolumn{2}{|c|}{ Prechange: both works } & \multicolumn{2}{|c|}{ Postchange: both works } \\
\hline & $O b s / \operatorname{Exp} A$ & $S M R A$ & $O b s / \operatorname{Exp} A$ & $S M R A$ & $O b s / E x p A$ & $S M R A$ \\
\hline $\begin{array}{l}20-29 \\
30-39 \\
40-49 \\
50-59 \\
60-69 \\
70-79 \\
80-84\end{array}$ & $\begin{array}{r}-1 / \\
1 / 0.07 \\
6 / 1.13 \\
20 / 6.73 \\
31 / 15.43 \\
23 / 11.67 \\
1 / 1.68\end{array}$ & $\begin{array}{r}-1429 \\
531 \\
297 \\
201 \\
197 \\
60\end{array}$ & $\begin{array}{r}0 / 0.04 \\
4 / 0.54 \\
10 / 4 \cdot 13 \\
30 / 15 \cdot 85 \\
34 / 20 \cdot 90 \\
14 / 10 \cdot 11 \\
1 / 0.72\end{array}$ & $\begin{array}{l}- \\
741 \\
242 \\
189 \\
163 \\
138 \\
139\end{array}$ & $\begin{array}{ll}0 / & 0.02 \\
0 / & 0.25 \\
3 / & 1.53 \\
6 / & 4.69 \\
4 / & 5.27 \\
1 / & 1.92 \\
0 / & 0.07\end{array}$ & $\begin{array}{r}- \\
169 \\
128 \\
76 \\
52 \\
-\end{array}$ \\
\hline Total & $82 / 36 \cdot 70$ & 223 & $93 / 52 \cdot 27$ & 178 & $14 / 13 \cdot 75$ & 102 \\
\hline
\end{tabular}

Table 7 Lung cancer mortality by job categories: Eaglescliffe and Rutherglen men with more than two years of work

\begin{tabular}{|c|c|c|c|c|c|c|c|c|c|c|c|c|}
\hline \multirow[b]{3}{*}{ Job groups } & \multicolumn{6}{|c|}{ Early and prechange men } & \multicolumn{6}{|c|}{ Postchange men } \\
\hline & \multicolumn{2}{|c|}{ Eaglescliffe } & \multicolumn{2}{|c|}{ Rutherglen } & \multicolumn{2}{|l|}{ Total } & \multicolumn{2}{|c|}{ Eaglescliffe } & \multicolumn{2}{|c|}{ Rutherglen } & \multicolumn{2}{|l|}{ Total } \\
\hline & Men & $O b s / \operatorname{Exp} A$ & Men & $O b s / \operatorname{Exp} A$ & $O b s / \operatorname{Exp} A$ & $S M R A$ & Men & $O b s / \operatorname{Exp} A$ & Men & $O b s / E x p A$ & $O b s / E x p A$ & $S M R A$ \\
\hline \multicolumn{13}{|l|}{ High exposure: } \\
\hline $\begin{array}{l}\text { Process, labourers } \\
\text { Tradesmens' mates } \\
\text { Transport } \\
\text { Total }\end{array}$ & $\begin{array}{r}344 \\
38 \\
13 \\
395\end{array}$ & $\begin{array}{r}52 / 19 \cdot 65 \\
5 / 1 \cdot 83 \\
2 / 0 \cdot 80 \\
59 / 22 \cdot 28\end{array}$ & $\begin{array}{r}423 \\
70 \\
30 \\
523\end{array}$ & $\begin{array}{r}75 / 31 \cdot 20 \\
11 / 6 \cdot 47 \\
6 / 1 \cdot 78 \\
92 / 39 \cdot 45\end{array}$ & $\begin{array}{r}127 / 50 \cdot 85 \\
16 / 8 \cdot 30 \\
8 / 2 \cdot 58 \\
151 / 61 \cdot 73\end{array}$ & $\begin{array}{l}250 \\
193 \\
310 \\
245\end{array}$ & $\begin{array}{r}241 \\
20 \\
29 \\
290\end{array}$ & $\begin{array}{l}3 / 2 \cdot 91 \\
0 / 0 \cdot 21 \\
1 / 0 \cdot 42 \\
4 / 3 \cdot 54\end{array}$ & $\begin{array}{r}48 \\
14 \\
5 \\
67\end{array}$ & $\begin{array}{l}2 / 1 \cdot 79 \\
0 / 0 \cdot 52 \\
0 / 0 \cdot 22 \\
2 / 2 \cdot 53\end{array}$ & $\begin{array}{l}5 / 4 \cdot 70 \\
0 / 0 \cdot 73 \\
1 / 0 \cdot 64 \\
6 / 6 \cdot 07\end{array}$ & $\begin{array}{r}106 \\
156 \\
99\end{array}$ \\
\hline \multicolumn{13}{|l|}{ Lower exposure: } \\
\hline $\begin{array}{l}\text { Skilled tradesmen } \\
\text { Yard, service, misc } \\
\text { Total }\end{array}$ & $\begin{array}{r}119 \\
19 \\
138\end{array}$ & $\begin{array}{ll}7 / 4 \cdot 25 \\
0 / & 1 \cdot 50 \\
7 / 5 \cdot 75\end{array}$ & $\begin{array}{r}115 \\
76 \\
191\end{array}$ & $\begin{array}{r}9 / 7 \cdot 79 \\
5 / 6.03 \\
14 / 13.82\end{array}$ & $\begin{array}{r}16 / 12 \cdot 04 \\
5 / 7 \cdot 53 \\
21 / 19 \cdot 57\end{array}$ & $\begin{array}{r}133 \\
66 \\
107\end{array}$ & $\begin{array}{r}79 \\
8 \\
87\end{array}$ & $\begin{array}{l}0 / 0.48 \\
1 / 0.39 \\
1 / 0.87\end{array}$ & $\begin{array}{l}45 \\
18 \\
63\end{array}$ & $\begin{array}{l}3 / 2 \cdot 02 \\
0 / 0 \cdot 63 \\
3 / 2 \cdot 65\end{array}$ & $\begin{array}{l}3 / 2 \cdot 50 \\
1 / 1 \cdot 02 \\
4 / 3 \cdot 52\end{array}$ & $\begin{array}{r}120 \\
98 \\
114\end{array}$ \\
\hline
\end{tabular}

Table 8 Lung cancer mortality by duration of service and interval after start of employment: postchange workers

\begin{tabular}{|c|c|c|c|c|c|c|c|}
\hline \multirow{3}{*}{$\begin{array}{l}\text { Years } \\
\text { from } \\
\text { start of } \\
\text { work }\end{array}$} & \multirow[b]{3}{*}{ Factory } & \multicolumn{4}{|c|}{ Duration of service (y) } & \multirow{2}{*}{\multicolumn{2}{|c|}{ Total }} \\
\hline & & 1 & $2-4$ & $5-9$ & $10+$ & & \\
\hline & & $O b s / E x p A$ & $O b s / E x p A$ & $O b s / E x p A$ & $O b s / E x p A$ & $O b s / \operatorname{Exp} A$ & $S M R A$ \\
\hline $1-4$ & $\begin{array}{l}\text { Rutherglen } \\
\text { Eaglescliffe } \\
\text { Both works }\end{array}$ & $\begin{array}{l}0 / 0 \cdot 23 \\
0 / 0 \cdot 21 \\
0 / 0 \cdot 44\end{array}$ & $\begin{array}{l}1 / 0 \cdot 23 \\
0 / 0.40 \\
1 / 0.63\end{array}$ & & & $\begin{array}{ll}1 / & 0.46 \\
0 / & 0.61 \\
1 / & 1.07\end{array}$ & 93 \\
\hline $5-14$ & $\begin{array}{l}\text { Rutherglen } \\
\text { Eaglescliffe } \\
\text { Both works }\end{array}$ & $\begin{array}{l}2 / 0 \cdot 78 \\
0 / 0 \cdot 50 \\
2 / 1 \cdot 28\end{array}$ & $\begin{array}{l}0 / 1 \cdot 05 \\
1 / 0 \cdot 28 \\
1 / 1 \cdot 33\end{array}$ & $\begin{array}{l}1 / 0 \cdot 38 \\
1 / 1 \cdot 21 \\
2 / 1 \cdot 59\end{array}$ & $\begin{array}{l}-1 / 0 \cdot 74 \\
1 / 0 \cdot 74\end{array}$ & $\begin{array}{l}3 / 2 \cdot 21 \\
3 / 2 \cdot 73 \\
6 / 4 \cdot 94\end{array}$ & 121 \\
\hline $15-24$ & $\begin{array}{l}\text { Rutherglen } \\
\text { Eaglescliffe } \\
\text { Both works }\end{array}$ & $\begin{array}{l}1 / 1 \cdot 46 \\
1 / 0 \cdot 39 \\
2 / 1 \cdot 85\end{array}$ & $\begin{array}{l}1 / 1 \cdot 75 \\
1 / 0 \cdot 21 \\
2 / 1 \cdot 96\end{array}$ & $\begin{array}{l}1 / 0.74 \\
0 / 0.41 \\
1 / 1 \cdot 15\end{array}$ & $\begin{array}{l}-1 / 1 \cdot 15 \\
1 / 1 \cdot 15\end{array}$ & $\begin{array}{l}3 / \\
3 / 95 \\
3 / 2 \cdot 16 \\
6 / 6 \cdot 11\end{array}$ & 98 \\
\hline$\geqslant 25$ & $\begin{array}{l}\text { Rutherglen } \\
\text { Eaglescliffe } \\
\text { Both works }\end{array}$ & $\frac{0 / 0.55}{0 / 0.55}$ & $\frac{0 / 0.56}{0 / 0.56}$ & $\frac{1 / 0 \cdot 48}{1 / 0 \cdot 48}$ & $\begin{array}{l}-\overline{0 / 0.01} \\
0 / 0.01\end{array}$ & $\begin{array}{ll}1 / & 1.59 \\
0 / & 0.01 \\
1 / & 1.60\end{array}$ & 63 \\
\hline Total & $\begin{array}{l}\text { Rutherglen } \\
\text { Eaglescliffe } \\
\text { Both works } \\
\text { SMRA }\end{array}$ & $\begin{array}{l}3 / 3 \cdot 02 \\
1 / 1 \cdot 10 \\
4 / 4 \cdot 12 \\
97\end{array}$ & $\begin{array}{l}2 / 3.59 \\
2 / 0 \cdot 89 \\
4 / 4 \cdot 48 \\
89\end{array}$ & $\begin{array}{r}3 / 1 \cdot 60 \\
1 / 1 \cdot 62 \\
4 / 3 \cdot 22 \\
124\end{array}$ & $\begin{array}{l}\overline{2 / 1} .90 \\
2 / 1.90 \\
105\end{array}$ & $\begin{array}{l}8 / 8 \cdot 21 \\
6 / 5 \cdot 51 \\
14 / 13 \cdot 72 \\
102\end{array}$ & $\begin{array}{r}97 \\
109\end{array}$ \\
\hline
\end{tabular}

Table 9 Details of the four cases of nasal cancer

\begin{tabular}{|c|c|c|c|c|c|c|c|c|c|}
\hline \multirow{2}{*}{$\begin{array}{l}\text { Case } \\
\text { No }\end{array}$} & \multirow[b]{2}{*}{ Factory } & \multirow{2}{*}{$\begin{array}{l}\text { Year } \\
\text { of } \\
\text { birth }\end{array}$} & \multicolumn{2}{|c|}{ Period of work } & \multirow[b]{2}{*}{ Main jobs } & \multirow{2}{*}{$\begin{array}{l}\text { Latent } \\
\text { interval } \\
(y)\end{array}$} & \multirow{2}{*}{$\begin{array}{l}\text { Year } \\
\text { of } \\
\text { death }\end{array}$} & \multirow{2}{*}{$\begin{array}{l}\text { Age } \\
(y)\end{array}$} & \multirow[b]{2}{*}{ Cancer site } \\
\hline & & & Dates & Years & & & & & \\
\hline $\begin{array}{l}1 \\
2\end{array}$ & $\begin{array}{l}\text { Rutherglen } \\
\text { Rutherglen }\end{array}$ & $\begin{array}{l}1897 \\
1908\end{array}$ & $\begin{array}{l}1911-62 \\
1933-39 \\
1945-68\end{array}$ & $\begin{array}{l}50 \\
28\end{array}$ & $\begin{array}{l}\text { Labourer, kilns, leaching } \\
\text { Electrician, foreman }\end{array}$ & $\begin{array}{l}53 \\
43\end{array}$ & $\begin{array}{l}1965 \\
1977\end{array}$ & $\begin{array}{l}67 \\
68\end{array}$ & $\begin{array}{l}\text { Maxillary antrum } \\
\text { Nasal epithelium }\end{array}$ \\
\hline $\begin{array}{l}3 \\
4\end{array}$ & $\begin{array}{l}\text { Eaglescliffe } \\
\text { Eaglescliffe }\end{array}$ & $\begin{array}{l}1917 \\
1933\end{array}$ & $\begin{array}{l}1952-75 \\
1953-83\end{array}$ & $\begin{array}{l}23 \\
29\end{array}$ & $\begin{array}{l}\text { Process worker, chrome oxide } \\
\text { Process worker, kilns, leaching }\end{array}$ & $\begin{array}{l}28 \\
29\end{array}$ & $\begin{array}{l}1980 \\
1983\end{array}$ & $\begin{array}{l}63 \\
49\end{array}$ & $\begin{array}{l}\text { Left nostril } \\
\text { "Nasal cancer" }\end{array}$ \\
\hline
\end{tabular}


category, and because information on early workers' jobs before 1949 was often lacking. Nevertheless, it appears that among early and prechange men a high risk was incurred by those with consistent moderate or high chromate exposure (process workers, labourers), or sporadic hïgh exposure (mates to skilled tradesmen, transport workers). A more modest risk was incurred by the skilled tradesmen, and the lowest risk by those whose exposure was mostly indirect (yard and miscellaneous service workers). The pattern for Bolton prechange workers appears similar, with the overall SMRA of 166 (obs/ expA 9/5.43) for men employed for two years or longer subdividing to obs/expA 9/4.53 (SMRA 199) for 103 men in the higher risk job groups, and obs/ $\operatorname{expA~} 0 / 0.90$ for the remaining 25 men.

Table 8 shows the lung cancer mortality of postchange workers analysed by latency and duration of service. The total number of observed deaths is close to that expected with no apparent pattern of risk with duration of work or interval since first employment. The reduction in risk for postchange men employed for at least two years compared with corresponding early and prechange workers is statistically significant $(p=0.026)$ after allowance for differences in age, duration of employment, and duration of observation. Table 3 does not show any unusual features in relation to date of first employment, and Table 7 gives no indication of the pattern of risk by job category found among early and prechange men. However, in Table 6 there is some suggestion of an excess of deaths below age 50 (SMRA 167, obs/expA $3 / 1 \cdot 80)$.

\section{NASAL CANCER}

All four nasal cancer deaths occurred among the groups with a clear risk of lung cancer-namely, Eaglescliffe and Rutherglen early and prechange workers. The total obs/expA values for these groups are 4/0.26 (SMRA 1538), a highly significant excess. Precise cancer sites are uncertain because clinical details were available only for case 3 ; this man had an undifferentiated carcinoma of the left nostril diagnosed in 1977, although in 1980 his death certificate specified carcinoma of the left maxillary antrum.

Table 9 provides some data about the four affected workers. Case 1 worked mainly on the kilns conveying high lime roast to the leaching area; he is believed to have suffered nasal ulceration. Case 2 worked in all parts of the works as an electrician (later a foreman electrician), and spent about 15 years at the factory before the main improvements began; it is not known whether he suffered nasal ulceration. Case 3 worked mainly with chrome oxide and had exposure to trivalent rather than hexavalent chromium, but details of his earliest work from 1952 to 1955 are not known; it is likely that his exposure was mixed, as he is known to have had nasal ulceration. Case 4 started work in late 1953, not long before the main plant improvements began, but he worked on the kilns, where exposures were most severe, and he is known to have suffered nasal ulceration.

All four men with nasal cancer had more than 20 years of exposure to chromates. For Case 3 the cancer was first diagnosed three years before death, and the latent intervals up to diagnosis or death thus range from 25 to 53 years. Only Case 4 was still employed when his tumour was diagnosed at the unusually early age of 49 . Cases 1 and 2 had retired three and eight years earlier, and Case 3 had retired five years earlier aged 58 after a stroke.

\section{OTHER NEOPLASMS}

Table 10 shows results for other neoplasms. Because numbers are small for individual cancer sites, values for early and prechange groups at each factory are combined. Attention is focussed on these groups because they showed the clearest excess of lung and nasal cancers, and were presumably those with the highest chromate exposures. Results were also examined for a subgroup of early and prechange workers at all three works combined employed for five years or longer, with observation commencing 10 years after first exposure. Any risk should show most clearly in this L5/010 subgroup.

No deaths from any of the cancer sites analysed for the groups shown have significant excesses, regardless as to whether adjusted or unadjusted expected values are used; similarly no significant excesses were found in the L5/010 subgroup. The total number of observed deaths shown for early and prechange workers combined (112) is close to the adjusted expected value $(110 \cdot 25)$, as is that for the $L 5 / 010$ subgroup (obs/expA 76/80.30). One significant deficit of deaths, for stomach cancer, exists at Eaglescliffe (obs/expA 4/10.31, SMRA 39).

The results for laryngeal tumours are of interest in view of the hazard for other respiratory cancers. Two laryngeal cancer deaths occurred among the early and prechange workers compared with $2 \cdot 29$ expected; one of the affected men worked for less than two years, and the other died only nine years after first exposure. There were two deaths among the postchange men compared with only 0.29 expected, but both men were employed for less than two years. There is therefore little evidence of a risk for laryngeal cancer.

Among the early and prechange workers the figures show non-significant excesses of cancers of the oesophagus, and of the mouth and pharynx, with SMRAs of 162 (obs/expA 9/5.56), and 217 (obs/expA $6 / 2.77$ ). In the L5/010 subgroup, however, the SMRA for oesophageal cancer drops to 124 (obs/ expA 5/4.03). The SMRA for cancers of the mouth and pharynx also drops slightly to 202 (obs/expA 
Table 10 Mortality from all neoplasms except lung and nasal cancers

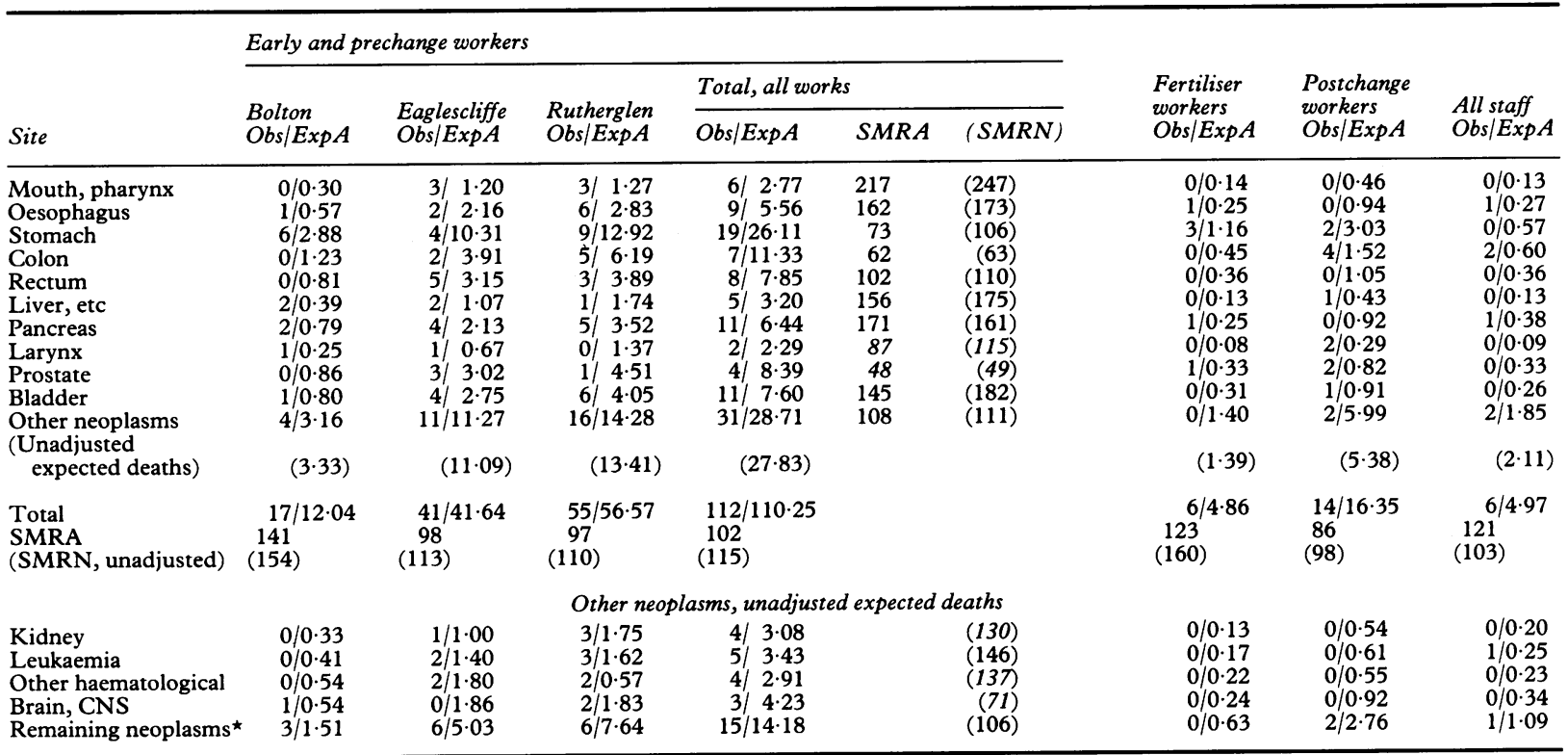

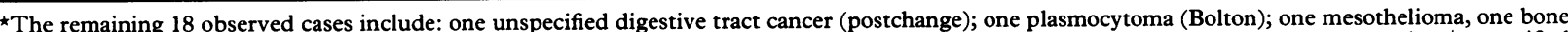

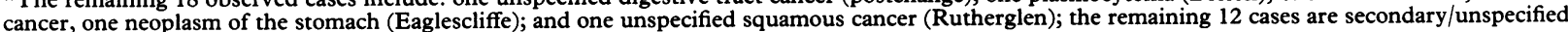
cancers.

4/1.98); the four cases comprise three cancers of the mouth and one of the tonsils. There are no cancers of these sites among the postchange workers.

Although stomach cancer may appear raised at Bolton, there is an overall deficit for early and prechange workers (obs/expA 19/26・11, SMRA 73); the result for the E5/L10 subgroup is similar (obs/ expA 13/19.25, SMRA 68). There are six cancers of the colon among postchange workers and staff but early and prechange workers show an overall deficit with a SMRA of 62 (59 in the L5/010 subgroup). Slight excesses are found for cancers of the pancreas
(SMRA 171) and bladder (SMRA 145), and a deficit for prostate cancers (SMRA 48); in the L5/010 subgroup the corresponding SMRAs are 147, 172, and 44 . None of these values are statistically significant.

\section{OTHER CAUSES OF DEATH}

Table 11 shows mortality from other causes. The SMRAs for all non-malignant causes decline from 96 for early groups to 90 for prechange workers and to 86 for postchange groups. Early workers at Eaglescliffe and Rutherglen have SMRAs of 97

Table 11 Deaths from causes other than neoplasms

\begin{tabular}{|c|c|c|c|c|c|c|}
\hline \multirow[b]{2}{*}{ Cause } & \multicolumn{3}{|l|}{ Early workers } & \multicolumn{3}{|c|}{ Prechange workers } \\
\hline & $O b s / \operatorname{Exp} A$ & $S M R A$ & $(S M R N)$ & $O b s / \operatorname{Exp} A$ & $S M R A$ & $(S M R N)$ \\
\hline $\begin{array}{l}\text { Ischaemic heart disease } \\
\text { Cercbrovascular disease } \\
\text { Chronic obstructive airways disease } \\
\text { Other causes } \\
\text { (Unadjusted expected deaths) }\end{array}$ & $\begin{array}{l}77 / 91 \cdot 79 \\
36 / 37 \cdot 84 \\
41 / 28 \cdot 66 \\
85 / 90 \cdot 19 \\
(75 \cdot 82)\end{array}$ & $\begin{array}{c}84 \\
95 \\
143^{\star} \\
94\end{array}$ & $\begin{array}{l}(93) \\
(112) \\
(206)^{\star} \\
(112)\end{array}$ & $\begin{array}{l}135 / 144 \cdot 28 \\
34 / 38 \cdot 10 \\
29 / 31 \cdot 90 \\
97 / 112 \cdot 97 \\
(93 \cdot 65)\end{array}$ & $\begin{array}{l}94 \\
89 \\
91 \\
86\end{array}$ & $\begin{array}{l}(107) \\
(109) \\
(129) \\
(110)\end{array}$ \\
\hline $\begin{array}{l}\text { All causes less neoplasms } \\
{ }^{\star} p<0.05 \text { (two tailed). }\end{array}$ & $239 / 248 \cdot 48$ & 96 & (113) & $295 / 327 \cdot 25$ & 90 & $(104)$ \\
\hline \multicolumn{7}{|c|}{ Other causes: unadjusted expected deaths } \\
\hline $\begin{array}{l}\text { Other circulatory diseases } \\
\text { Other respiratory diseases } \\
\text { Accidents, etc } \\
\text { Remaining causes }\end{array}$ & $\begin{array}{l}38 / 26 \cdot 87 \\
14 / 15 \cdot 47 \\
13 / 8 \cdot 13 \\
20 / 25 \cdot 35\end{array}$ & & $\begin{array}{r}(141) \\
(90) \\
(160) \\
(79)\end{array}$ & $\begin{array}{l}34 / 26 \cdot 98 \\
14 / 15 \cdot 96 \\
24 / 18 \cdot 73 \\
25 / 31 \cdot 98\end{array}$ & & $\begin{array}{r}(126) \\
(88) \\
(128) \\
(78)\end{array}$ \\
\hline
\end{tabular}

${ }^{\star} p<0.05$ (two tailed). 
(obs/expA 46/47-28) and 93 (obs/expA 166/179.21), but for Bolton workers the SMRA is 123 (obs/expA 27/21.99), mainly due to an excess of deaths from respiratory diseases. In the prechange groups Bolton men again have the least favourable mortality with a SMRA of 101 (obs/expA 43/42.52), compared with 95 (obs/expA 125/131.16) for Rutherglen, and 83 (obs/expA 127/153.57) for Eaglescliffe. All salaried staff combined have a slightly raised SMRA of 108, but whereas the SMRA for prechange staff is 126 (obs/expA 20/15.92), that for postchange staff is only 56 (obs/expA 3/5.37). The highest mortality is found among the fertiliser workers (SMRA 133).

Some deficits of deaths are found from ischaemic heart disease, but these are largely offset by excesses for other circulatory diseases, and the total observed deaths from all circulatory diseases among payroll workers (including the fertiliser group) are close to those expected.

Mortality from chronic obstructive airways diseases is significantly raised in the combined early groups; Bolton workers have the highest SMRA of 237 (obs/expA 7/2.96), compared with $130(8 / 6 \cdot 15)$ for Eaglescliffe and 133 (26/19.57) for Rutherglen. The SMRA for the combined prechange groups drops to 91, and the SMRA of 17 for all postchange workers is significantly low. Mortality from other respiratory diseases also declines over time. Fertiliser workers have the worst respiratory mortality, whereas no deaths occur among the staff.

The excess of deaths from accidental and violent causes is largely accounted for by eight deaths due to works accidents at Rutherglen: six in early workers, and one each in prechange workers and prechange staff. Most resulted from a boiler explosion in the 1950 s. No deaths occurred from works accidents at the other factories. No significant excesses or deficits in mortality were found for any of the other causes listed in the Materials and methods section.

\section{Discussion}

This report analyses a total of 175 deaths from lung cancer among 1422 Rutherglen and Eaglescliffe early and prechange workers, and has long observation periods. By December 1988 at least 28 years had elapsed since first exposure for prechange men, and at least 44 years for early workers. Only 63 early workers were still living by 1988 , mostly aged over 70. It therefore seems unlikely that the addition of future data for these groups will materially alter the present pattern of results.

A difficulty in all studies of occupational lung cancer is the choice of appropriate reference rates, as the disease is closely linked to smoking, and as rates vary widely between different populations. In the absence of reliable smoking data we have attempted to calculate suitable rates by adjusting national death rates by factors based on area and social class. ${ }^{27}$ Because the factories are located in areas with high lung cancer rates and because manual workers also have above average rates, the adjustment factors are substantial (128 at Eaglescliffe, 151 at Rutherglen, and 137 at Bolton). The factors are based on data relating to years around the 1971 census, but examination of data for years around 1981 suggests that factors based on more recent data would be similar. Nevertheless, uncertainty in reference rates implies that the SMRs may perhaps be overestimated or underestimated by up to $25 \%$. Such inaccuracy would not affect the patterns of risk with duration of employment, time since first exposure, or age at death, but could affect the interpretation of the results for postchange workers.

The overall relative risk for lung cancer among early and prechange workers at Eaglescliffe and Rutherglen is about twofold (obs/expA 175/88.97, SMRA 197). The somewhat higher risk found in the 1981 United Kingdom report ${ }^{4}$ is attributable mainly to the use of unadjusted national death rates.

An important feature of these results is the persistent high relative risk even after long latent intervals. The relative risk rises to about twofold during 15-24 years after first exposure, and remains roughly constant up to 40 years. Thereafter the risk appears

\begin{tabular}{|c|c|c|c|c|c|c|c|c|}
\hline \multicolumn{3}{|c|}{ Postchange workers } & \multicolumn{3}{|c|}{ Fertiliser workers } & \multicolumn{3}{|l|}{ All staff } \\
\hline$O b s / \operatorname{Exp} A$ & $S M R A$ & $(S M R N)$ & $O b s / \operatorname{Exp} A$ & $S M R A$ & $(S M R N)$ & $O b s / \operatorname{Exp} A$ & $S M R A$ & $(S M R N)$ \\
\hline $\begin{array}{c}32 / 35 \cdot 42 \\
9 / 7 \cdot 70 \\
1 / 5 \cdot 88 \\
21 / 28 \cdot 13 \\
(23 \cdot 48)\end{array}$ & $\begin{array}{c}90 \\
117 \\
17^{\star} \\
75\end{array}$ & $\begin{array}{r}(103) \\
(139) \\
(24) \\
(89)\end{array}$ & $\begin{array}{l}12 / 10 \cdot 20 \\
4 / 2 \cdot 58 \\
4 / 2 \cdot 32 \\
10 / 7 \cdot 46 \\
(6 \cdot 48)\end{array}$ & $\begin{array}{l}118 \\
155 \\
172 \\
134\end{array}$ & $\begin{array}{l}(142) \\
(195) \\
(237) \\
(156)\end{array}$ & $\begin{array}{l}12 / 10 \cdot 76 \\
3 / 2 \cdot 39 \\
0 / 0.95 \\
8 / 7 \cdot 19 \\
(9 \cdot 81)\end{array}$ & $\begin{array}{l}112 \\
\frac{126}{111}\end{array}$ & $\begin{array}{r}(100) \\
(106) \\
\left(-\frac{}{82}\right) \\
(82)\end{array}$ \\
\hline $63 / 77 \cdot 13$ & 86 & (97) & $\begin{array}{l}30 / 22 \cdot 56 \\
(18 \cdot 65)\end{array}$ & 133 & $(161)^{\star}$ & $23 / 21 \cdot 29$ & 108 & (86) \\
\hline $\begin{array}{l}4 / 5 \cdot 23 \\
2 / 3 \cdot 07 \\
9 / 7 \cdot 36 \\
6 / 7 \cdot 82\end{array}$ & & $\begin{array}{r}(76) \\
(65) \\
(122) \\
(77)\end{array}$ & $\begin{array}{l}0 / 1 \cdot 98 \\
4 / 1 \cdot 11 \\
2 / 1 \cdot 28 \\
4 / 2 \cdot 11\end{array}$ & & $\begin{array}{l}(-) \\
(360) \\
(156) \\
(190)\end{array}$ & $\begin{array}{l}3 / 2 \cdot 44 \\
0 / 1 \cdot 40 \\
3 / 2 \cdot 71 \\
2 / 3 \cdot 26\end{array}$ & & $\begin{array}{r}(123) \\
(-) \\
(111) \\
(61)\end{array}$ \\
\hline
\end{tabular}


The risk for the tradesmen also appears lower than that of their unskilled or semiskilled mates (SMRA 193) who may have carried out the dirtiest maintenance jobs. The excess among the skilled tradesmen, however, may be understated to some extent because the adjustment factors for lung cancer used are appropriate to semiskilled workers (social class IV) rather than skilled manual workers (class III manual); the tradesmen belong to class III manual, which has generally lower death rates from lung cancer. Nevertheless, even allowing for a $20 \%$ understatement of risk among the tradesmen, raising the SMRA from 133 to 166 , their risk is still lower than that of the process workers and labourers. De Marco $e t a l^{17}$ also found that the relative risk was highest among men in the departments where exposure to chromium compounds was greatest.

Exposures at Bolton were similar in nature to those at Eaglescliffe and Rutherglen. Although results shown in table 2 fail to provide clear evidence of excess deaths from lung cancer, the same patterns of risk in relation to age and jobs are found, and it is prudent to assume that workers there did incur some risk. The early group at Bolton includes only $37 \mathrm{men}$, and the prechange group is also small and is subject to some imprecision due to the number of men lost to follow up; in particular, 14 out of 70 pre-1956 starters were lost, and some cases of lung cancer could have been missed. The workers at Bolton show excess deaths from other cancers and from non-malignant diseases, giving no reason to suppose that the adjustment factors are too high.

Clearly the overall relative risk of 197 for early and prechange workers at Eaglescliffe and Rutherglen is the average of a wide range of SMRAs, varying from 250 for highly exposed workers staying for two years or longer down to marginal risks for men in the least exposed jobs or those staying less than two years. Any risk among salaried staff also appears marginal. Only one death from lung cancer was seen among prechange staff $(\operatorname{expA} 1.95)$, and none among postchange staff (expA $0 \cdot 58$ ). The employee who died was only 52 and had prolonged exposure to hexavalent chromium compounds while working as a laboratory technician; this exposure may have caused or contributed to his death.

No indication of a lung cancer risk affecting the Eaglescliffe fertiliser workers exists, although this group had worse mortality from non-malignant causes (SMRA 133) than the Eaglescliffe chromate workers, especially from respiratory diseases. Although only three fertiliser workers were lost to follow up numbers are small, and the SMRA of 76 (obs/expA 3/3.95) has a wide $95 \%$ confidence interval of $0 \cdot 16-2 \cdot 22$.

Apart from these differences in lung cancer risk according to duration and level of exposure, the results for 1955-60 entrants at Eaglescliffe suggest that even before the change to a no-lime process the overall risk there may have been reduced by the programme of process and hygiene improvements started in 1955. Whereas men who started work during 1945-54 and stayed at least two years have a high SMRA of 292 based on 42 deaths (including nine under the age of 50), the SMRA for corresponding 1955-60 entrants is lower at 153 (obs/expA $10 / 6.54)$, with no deaths under 50 . During 5-29 years after first employment, however, 1955-60 entrants also showed lower mortality from all other causes combined, with a SMRA of 67 compared with one of 107 for 1945-54 entrants and it is possible that these lower SMRAs are partly attributable to changes in the selection of new workers.

The mortality results for postchange workers fail to show excess deaths at either Eaglescliffe or Rutherglen (combined SMRA 102, obs/expA $14 / 13 \cdot 72$ ), and no longer show the earlier pattern of risk in relation to jobs, duration of service, or interval after first employment. It is clear that the risk has diminished for postchange workers, but it is not possible to distinguish whether the decline in the risk is attributable to the introduction of low-lime and no-lime processes or to general reductions in exposure to chromate. Equally it is not possible to conclude that the risk has ceased. In the first place, the $95 \%$ confidence interval around the SMRA of 102 is wide (56-171) because of small numbers. Secondly, these workers have so far been observed for only 12-29 years depending on their dates of starting, and most have not yet reached those intervals after first exposure where the excess of deaths among earlier workers approached its peak.

A third reason for caution is that there have been several lung cancer cases at young ages among postchange workers. Of the three deaths under 50 included in the analysis, two occurred at Rutherglen $(\operatorname{expA} 1.02)$ and one at Eaglescliffe $(\operatorname{expA} 0 \cdot 76)$. Also, there are four known cases excluded from the analysis: one Rutherglen worker with lung cancer died aged 46 in 1973 with death attributed to other causes, and three Eaglescliffe workers have been treated for the disease at the ages of 39,49 , and 48 , in 1978,1986 , and 1990. Since cases at young ages have been seen to be a marker of the lung cancer risk among chromate workers, judgement must be reserved on the question of whether some level of risk has persisted among postchange workers, particularly at Eaglescliffe.

The four deaths found from cancers of the nose and nasal sinuses constitute a marked excesş, as these tumours are normally rare. All four men were employed for over 20 years, and spent at least part of this time in jobs with high levels of exposure. Given the considerable number of heavily exposed early workers who had already completed 20 years' service when they entered observation in 1950, it is surpris- 
ing that the first two deaths did not occur until 1965 and 1977 after exposures starting in 1911 and 1933. The two more recent deaths among Eaglescliffe pre 1955 prechange workers occurred after shorter latent intervals of nearly 30 years, but the absence of any further deaths since 1983 suggests that these may be isolated cases. Fewer than 40 early workers with 20 or more years' employment are still living, and because the Rutherglen factory closed in 1967 few prechange workers there attained 20 years' service. There remain some 50 Eaglescliffe pre 1955 prechange workers employed for over 20 years.

A total of 11 nasal cancers have been reported among other groups of chromate workers, but details of these are lacking. Enterline ${ }^{10}$ reported two maxillary sinus cancers at the plants studied by Taylor ${ }^{9}$ and himself, and Mancuso (personal communication) reported two nasal sinus cancers among 1938-48 entrants at an Ohio plant. No cases occurred at the two German factories studied by Korallus et al,${ }^{16}$ but Baetjer ${ }^{1}$ had found one case reported in Germany. In Japan Satoh et al ${ }^{15}$ reported the remarkable total of five deaths from cancer of the maxillary sinus and one from cancer of the nasal cavity among the 896 men they studied. In three out of the four United Kingdom cases the workers are known to have suffered previous nasal ulceration, but given the high frequency of this condition in past years it is unclear to what extent ulceration is an indication of risk for nasal cancer.

The results of this study do not suggest that chromate workers have been at risk of developing cancers of any other sites. Negative results have also been reported by Hayes et al,,$^{13}$ who distinguished cancers of the digestive tract and residual cancers, and Satoh et al, ${ }^{15}$ who distinguished stomach cancer, liver cancer, and residual cancers. De Marco et al ${ }^{17}$ found a non-significant excess of deaths from laryngeal cancer (obs/exp 3/1.04), and a highly significant excess of pleural mesotheliomas (obs/exp $3 / 0 \cdot 10$ ), but no other studies have implicated either site and the pleural tumours are presumably related to exposure to asbestos. Enterline ${ }^{10}$ found a non-significant excess of deaths from stomach cancer (obs/exp $16 / 10 \cdot 4$ ), but other studies have shown normal or low mortality for this site.

The totality of the evidence from this and other studies thus suggests that the occupational cancer risk for chromate production workers is restricted to cancers of the lung, nose, and nasal sinuses. This is a similar pattern to that seen in nickel refining, though it should be noted that for both cancers the risk for chromate workers is less pronounced than that for early nickel refining workers. ${ }^{28}$

The present report presents relatively straightforward analyses of risk in relation to factors such as age, duration of employment, and time since first employment. For a fuller understanding of the effects of these different factors, however, it is necessary to analyse them all simultaneously. This approach will be explored in a further report, which will also examine the limited data on smoking habits. It is important that observation of the study population continues; mortality data over the next 10 years may clarify the lung cancer situation in respect of postchange workers, and may also clarify the scale of the risk of nasal cancer.

\section{Postscript}

As at 11 February 1991 seven new cases of lung cancer have occurred among Eaglescliffe postchange workers since 31 December 1988. Two men have died and five other cases have been diagnosed, the three most recent in December 1990 and January and February 1991. All seven cases have occurred among men who started work before 1970 and were employed for more than 10 years.

\section{Appendix: estimation of area and social class adjusted rates}

Age specific mortalities for small areas and particular social classes are generally unreliable due to the small numbers of deaths. Adjusted death rates for each disease of interest have therefore been estimated by multiplying the national age specific rates by a suitable factor, on the assumption that the ratio of the death rate in the sub-population to the national rate is roughly constant across age and periods.

For social class, this adjustment factor is the published SMR for that social class compared with the national death rates $\left(\mathrm{SC}_{\mathrm{i}}\right.$ for social class $\left.\mathrm{i}\right)$. Similar SMRs are obtained for the area adjustment $\left(\mathrm{SA}_{\mathrm{j}}\right.$ for area $j$ ). To adjust for social class $i$ within area $j$ we use adjustment factors of the form:

$$
\frac{\mathrm{SC}_{\mathrm{i}} \times \mathrm{SA}_{\mathrm{j}}\left(\sum \mathrm{u}_{\mathrm{k}} \mathrm{SC}_{\mathrm{k}}\right)}{\sum \mathrm{w}_{\mathrm{k}} \mathrm{SC}_{\mathrm{k}}}
$$

where $w_{k}$ is the proportion of the male workforce in the given area in social class $\mathrm{k}, \mathrm{u}_{\mathrm{k}}$ is the corresponding national proportion, and summation is over all social classes. This type of adjustment takes into account that some of the variation in mortality by area is accounted for by variations in the social class distribution.

Area SMRs for Eaglescliffe and Bolton were based on the area mortality data for England and Wales during 1968-1978 provided by the Medical Research Council Environmental Epidemiology Unit. ${ }^{21}{ }^{22}$ For Eaglescliffe, about one third of the workforce were resident in the area formerly defined as Stockton Rural District, Durham (now part of Stockton District), with most of the remainder living in areas then included in Teesside County Borough, north 
Yorkshire. The area SMRs used were therefore an average of the SMRs for Teesside County Borough and Stockton Rural District weighted in the ratio 2:1. Similarly the adjustment factors for the Bolton workforce were calculated as a weighted average of the SMRs for the urban districts of Farnworth and Little Lever combined, and the County Borough of Bolton, weighted in the ratio $2: 1$; all these areas now form part of Bolton District, Greater Manchester.

For the Rutherglen workforce, area adjustment factors were calculated from SMRs for the Clydeside conurbation, relative to the Scottish national rates, using published rates for the period 1969-73. ${ }^{26}$ Although mortality is generally somewhat higher in Glasgow than in the remainder of Clydeside (particularly from lung cancer), about half the study population lived in Rutherglen and other areas outside Glasgow as defined at that period.

For Eaglescliffe and Bolton social class SMRs based on men aged 15-64 were obtained from published data based on the 1971 census and mortality in the years $1970-72 .^{20}$ These data were chosen as being based on a period central to the observation period of the study. SMRs based on the 1981 census were examined, and their use would have made only slight differences to the results. Social class IV SMRs were used for the payroll workers; social class II SMRs were used for the salaried staff without area adjustment (see text).

Mortality data by social class were not available for Scotland from the 1971 census, and SMRs were therefore estimated from the England and Wales SMRs $\left(\mathrm{SC}_{\mathrm{i}}\right)$, assuming that rates by social class were in the same proportion in each country. The SMR for class $\mathrm{i}$ is therefore given by:

$$
\frac{S C_{i}\left(\sum u_{j} S C_{j}\right)}{\sum w_{j} S C_{j}}
$$

where $u_{i}$ is the proportion of the England and Wales workforce in social class $j$, and $w_{j}$ is the corresponding proportion in Scotland.

Table 12 shows the resulting adjustment factors. For a few cancer sites (indicated in the table) adjustments could be made only by class and county or by class alone, due to lack of area data.

We are grateful to the Office of Population Censuses and Surveys, the NHS Central Register, the Scottish General Register Office, the Department of Health and Social Services, and Pension Fund administrators for tracing the vital state of the study population. The study was funded by British Chrome and Chemicals. The Institute of Cancer Research receives support from the Cancer Research Campaign and the Medical Research Council.

1 Baetjer AM. Pulmonary carcinoma in chromate workers. I. A review of the literature and report of cases. Arch Ind Hyg Occup Med 1950;2:487-504.
2 Bidstrup PL. Carcinoma of the lung in chromate workers. $\mathrm{Br} J$ Ind Med 1951;8:302-5.

3 Bidstrup PL, Case RAM. Carcinoma of the lung in workmen in the bichromate producing industry in Great Britain. $\mathrm{Br} J$ Ind Med 1956;13:260-4.

4 Alderson MR, Rattan NS, Bidstrup L. Health of workmen in the chromate-producing industry of Great Britain. $\mathrm{Br} \mathrm{J}$ Ind Med 1981;38:117-24.

5 Machle W, Gregorius F. Carcinoma of the respiratory system in the United States chromate-producing industry. Public Health Rep 1948;63:1114-27.

6 Baetjer AM. Pulmonary carcinoma in chromate workers. 2. Incidence on basis of hospital records. Arch Ind Hyg Occup Med 1950;2:505-16.

7 Mancuso TF, Hueper WC. Occupational cancer and other health hazards in a chromate plant: a medical appraisal. 1 . Lung cancers in chromate workers. Industrial Medicine and Surgery 1951;20:358-63.

8 US Public Health Service. Gafafer WM, ed. Health of workers in chromate producing industry. Washington DC: USPHS, 1953. (Pub No 192.)

9 Taylor FH. The relationship of mortality and duration of employment as reflected by a cohort of chromate workers. $\mathrm{Am} \mathrm{J}$ Public Health 1966;56:218-29.

10 Enterline PE. Respiratory cancer among chromate workers. J Occup Med 1974;16:523-6.

11 Mancuso TF. Consideration of chromium as an industrial carcinogen. In: Hutchinson TC, ed. Proceedings of the international conference on heavy metals in the environment. Toronto: Institute for Environmental Studies, 1975:343-56.

12 Hill WJ, Ferguson WS. Statistical analysis of epidemiological data from a chromium chemical manufacturing plant. J Occup Med 1979;21:103-6.

13 Hayes RB, Lilienfeld AM, Snell LM. Mortality in chromium chemical production workers: a prospective study. Int $J$ Epidem 1979;8:365-74.

14 Ohsaki Y, Abe S, Kimura K, et al. Lung cancer in Japanese chromate workers. Thorax 1978;33:372-4.

15 Satoh K, Fukuda Y, Torii K, Katsuno N. Epidemiological study of workers engaged in the manufacture of chromium compounds. J Occup Med 1981;23:835-8.

16 Korallus $U$, Lange $H$, Neiss A, Wustefeld E, Zwinger W Relationships between hygiene measures and bronchial carcinoma mortality in the chromate-producing industry. Arbeitsmedizin Socialmedizin Präventivmedizin 1982;17: 159-67.

17 de Marco R, Bernardinelli L, Mangione MP. Rischio di morte per tumori dell'apparato respiratorio in lavoratori addetti alla produzione di cromati. Med Lav 1988;79:368-76.

18 Levy LS, Martin PA, Bidstrup PL. Investigation of the potential carcinogenicity of a range of chromium containing materials on rat lung. $\mathrm{Br} J$ Ind Med 1986;43:243-56.

19 Coleman M, Douglas A, Herman C, Peto J. Cohort study analysis with a Fortran computer program. Int J Epidemiol 1986;15:134-7.

20 Office of Population Censuses and Surveys. Occupational Mortality: the Registrar General's decennial supplement for England and Wales, 1970-72. London: HMSO, 1978. (Series DS No 1.)

21 Gardner MJ, Winter PO, Taylor CP, Acheson ED. Atlas of cancer mortality in England and Wales 1968-1978. Chichester: John Wiley and Sons, 1983.

22 Gardner MJ, Winter PO, Barker DJP. Atlas of mortality from selected diseases in England and Wales 1968-1978. Chichester: John Wiley and Sons, 1984.

23 Office of Population Censuses and Surveys. Census 1971 . England and Wales economic activity county leaflets: Lancashire, Yorkshire North Riding, Durham. London: HMSO, 1975.

24 General Register Office, Edinburgh. Census 1971, Scotland. Population tables. Edinburgh: HMSO, 1974.

25 General Register Office, Edinburgh. Annual reports of the Register General for Scotland 1969-73. Part I: Mortality statistics. Nos 115-19. Edinburgh: HMSO, 1970-1974.

26 Office of Population Censuses and Surveys, General Register Office. Census 1971 Great Britain: Economic activity part IV (10\% sample). London: HMSO, 1975.

27 Doll R. Occupational Cancer: Hazards for Epidemiologists. Int J Epidemiol 1985;14:22-31.

28 Doll R, Mathews JD, Morgan LG. Cancer of the lung and nasal sinuses in nickel workers; a reassessment of the period of risk. $B r J$ Ind Med 1977;34:102-5.

Accepted 5 November 1990 